\title{
CORRELATION OF LOWER LIMB MUSCLES AND BODY MASS INDEX WITH BODY BALANCE IN THE ELDERLY
}

\author{
Natasya Valentina ${ }^{1}$, Patricia M Kurniawati ${ }^{2 *}$, Margarita M Maramis ${ }^{3}$ \\ ${ }^{1}$ Faculty of Medicine, Widya Mandala Catholic University of Surabaya, Indonesia, ${ }^{2}$ Department of Physical Medicine \\ and Rehabilitation, Faculty of Medicine, Universitas Airlangga, Surabaya, Indonesia, ${ }^{3}$ Department of Psychiatry, \\ Faculty of Medicine, Universitas Airlangga, Surabaya, Indonesia
}

\begin{abstract}
Indonesia enters the ageing population because of increasing elderly population. The large number of ederly population can have negative impact if they have some problems, such as increased disability and increased rates of life dependence. Based on health research, it was mentioned that the cause of the most injuries to the elderly group is falls that are caused by balance disorder. Balance problems can be caused by changes of musculoskeletal function. In addition, Body Mass Index (BMI) is still a problem that often occurs in the elderly that can affect daily activities. The objective of this study was to prove that lower limb muscle strength and BMI have correlation with body balance in the elderly. This study used a cross-sectional method carried out on individuals from affordable populations with Kendall Tau $C$ data analysis. Thirty-nine respondents were selected based on inclusion and exclusion criteria. Data were taken from these respondents on weight and height measurement for BMI, size of lower limb muscle strength using a leg dynamometer, and body balance based on risk of falls using Berg's balance scale. We obtained significant score 0,000 for correlation between lower limb muscle strength with body balance in elderly, and correlation between BMI with body balance in elderly. In conclusion, there is strong positive correlation between lower limb muscle strength with body balance in elderly. It is shown by the better muscle strength; the risk of falling in the elderly is getting lower. There is strong positive correlation between BMI with body balance in elderly. It is shown by increasing BMI away from normal scale; the risk of falling is higher.
\end{abstract}

Keywords: Elderly; lower limb muscle strength; Body Mass Index (BMI); body balance, falls

\section{ABSTRAK}

Indonesia memasuki ageing population karena jumlah lansianya yang terus meningkat. Besarnya jumlah lansia dapat berdampak negatif apabila lansia mengalami peningkatan disabilitas dan meningkatkan angka ketergantungan hidup. Berdasarkan riset kesehatan disebutkan bahwa penyebab cedera terbanyak pada lansia adalah jatuh yang dapat disebabkan oleh gangguan keseimbangan. Masalah keseimbangan dapat disebabkan oleh perubahan fungsi muskuloskeletal. Selain itu, Indeks Massa Tubuh (IMT) juga masih menjadi masalah yang sering terjadi pada lansia yang dapat mempengaruhi aktivitas sehari-hari. Tujuan penelitian ini adalah membuktikan bahwa kekuatan otot tungkai bawah dan IMT berkorelasi dengan keseimbangan tubuh pada lansia. Penelitian ini menggunakan metode cross-sectional yang dilakukan pada individu dari populasi terjangkau dengan analisa data Kendall Tau C. Tiga puluh sembilan responden yang terpilih berdasarkan kriteria inklusi dan ekslusi diambil datanya mengenai pengukuran berat dan tinggi badan untuk IMT, besar kekuatan otot tungkai bawah menggunakan alat leg dynamometer, dan keseimbangan tubuh berdasarkan resiko jatuh menggunakan skala keseimbangan Berg. Didapatkan nilai signifikansi 0,000 untuk korelasi kekuatan otot tungkai bawah dengan keseimbangan tubuh pada lansia, dan korelasi IMT dengan keseimbangan tubuh pada lansia. Sebagai simpulan, terdapat korelasi positif kuat untuk korelasi kekuatan otot tungkai bawah dan keseimbangan tubuh pada lansia. Semakin bagus kekuatan otot maka resiko jatuh pada lansia juga semakin rendah. Terdapat korelasi positif kuat untuk korelasi IMT dengan keseimbangan tubuh pada lansia. Semakin IMT menjauhi normal maka resiko jatuh semakin tinggi.

Kata kunci: Lansia; kekuatan otot tungkai bawah; Indeks Massa Tubuh (IMT); keseimbangan tubuh, jatuh

Correspondence: Patricia M. Kurniawati, Department of Physical Medicine and Rehabilitation, Faculty of Medicine, Widya Mandala Catholic University of Surabaya, Jalan Kalisari Selatan No. 1 Surabaya, Indonesia.

pISSN:2355-8393 • eISSN: 2599-056x • doi: http://dx.doi.org/10.20473/fmi.v54i4.10704

- Fol Med Indones. 2019;55: • Received 30 Jan $2019 \bullet$ Accepted 6 Mar 2019

- Open access under CC-BY-NC-SA license • Available at https://e-journal.unair.ac.id/FMI/ 


\section{INTRODUCTION}

Based on Law Number 13 of 1998 concerning Elderly Welfare, elderly is someone who has reached the age of 60 years and over. Globally, the number of elderly population is predicted to continue to increase. Similarly, the number of elderly population in Indonesia is predicted to increase higher than elderly population in the world after 2100 (Indonesia, 2018). The high number of elderly people in Indonesia can have a negative impact if they have problems such as decline in health, which results in increased disability, and a decrease in income, thus increasing the rate of dependency. Physiologically, elderly will experience aging process, ie. the process of slow disappearance of the ability of the tissue to improve themselves and maintain their normal structure and function, so they cannot survive against injury and repair damage (Darmojo \& Martono, 2015).

The 2013 Republic of Indonesia Basic Health Research (Riskesdas) data stated that the most causes of injury were falls, comprising as much as $49.5 \%$ in $55-64$ age group, $67.1 \%$ in $65-74$ age group, and $78.2 \%$ in older ages in more than 75 years (Research \& Development, 2013). Falls due to balance disorders that often occur in the elderly is a result of various changes in organ function, disease, and environmental factors. Organ function changes that affect the incidence of falls in the elderly include neurological, sensory, and musculoskeletal functions. In the musculoskeletal system, muscle strength is an important factor that has an effect on physical activity. In addition to changes in the musculoskeletal system due to the aging process, muscle strength can also decrease due to lack of movement or daily physical activity causing muscle atrophy (Jung \& Yamasaki, 2016).

Not ideal body weight is still a problem today and can cause various diseases. The percentage of underweight elderly population in Indonesia living is as much as $28.3 \%$, those with ideal body weight $42.4 \%$, overweight $6.7 \%$, and obesity $3.4 \%$. Ideal body mass index is important as it affects daily physical activity. If it is not ideal, the energy needed to carry out activities is also insufficient and causes the elderly to become weak and to reduce their physical activity, so that if left unchecked it will cause muscle atrophy in the elderly to occur faster and affect the balance of the body. Similarly, excessive weight can also affect the body's balance (Prasetya \& Yoga, 2015)

Balance disorders cause the elderly to limit their activities due to fear of falls or repeated falls in those who have experienced falls before. This makes them to withdraw themselves from outside environment and become dependent on other people around them. Therefore, it is important to prevent falls in this age group because, if they have ever experienced falls, complications will certainly occur easily, ranging from mild to severe injuries, or to fatality. This study was conducted to determine the correlation of lower limb muscle strength and body mass index with body balance in the elderly, because the Indonesian people still lack awareness about the importance of preventing falls, a problem that often occurs in the elderly.

\section{MATERIALS AND METHODS}

This study was an observational analytic study with a cross-sectional method at the Nursing Home Panti Surya Surabaya. This study had obtained ethical clearance from the Ethics and Research Commission, Faculty of Medicine, University of Widya Mandala, Surabaya. Sampling was done in total sampling. From a population of 79 people, 39 people were selected in accordance with the inclusion and exclusion criteria. Lower limb muscle strength was measured by leg dynamometer with criteria, for males:> 241 excellent, 240-214 good, 213-160 average, 159-137 below average, and $<137$ poor. For females, $>136$ excellent, 135-114 good, 113-66 average, 65-49 below average, and <49 poor (Heyward, H., Gibson, \& Ann, 2014). For the elderly, there is an additional $10 \%$ of the numbers obtained from the leg dynamometer as compensation for the aging process. Body mass index (BMI) values were obtained from the calculation of weight $(\mathrm{kg}) \div$ height 2 (m2) with criteria from the Ministry of Health of the Republic of Indonesia, for males: thin $<18 \mathrm{~kg} / \mathrm{m} 2$, normal $18-25 \mathrm{~kg} / \mathrm{m} 2$, overweight $25-27 \mathrm{~kg} / \mathrm{m} 2$, obesity $>27 \mathrm{~kg} / \mathrm{m} 2$, for females: thin: $<17 \mathrm{~kg} / \mathrm{m} 2$, normal: 17 - $23 \mathrm{~kg} / \mathrm{m} 2$, overweight: $23-27 \mathrm{~kg} / \mathrm{m} 2$, obesity $>27 \mathrm{~kg} / \mathrm{m}$. Balance was measured by Berg Balance Scale (BBS) which consisted of 14 simple questions from the researchers with a score of 0-4. The calculation results were interpreted to assess the risk of falls as follows: 0-20: high risk of falls, 21-40: moderate risk of falls, and 41-56: low risk of falls. This BBS test requires a ruler, 1 chair with arms, 1 chair without arms, stopwatch, and footstool (Berg K, Wood-Daphinee S, William JI, n.d. 1989). Data analysis used Kendall Tau C.

\section{RESULTS}

\section{Characteristics of respondents}

Respondents of this study consisted of 11 (28.2\%) males and 28 females (71.8\%), as can be seen in Table 1 . 


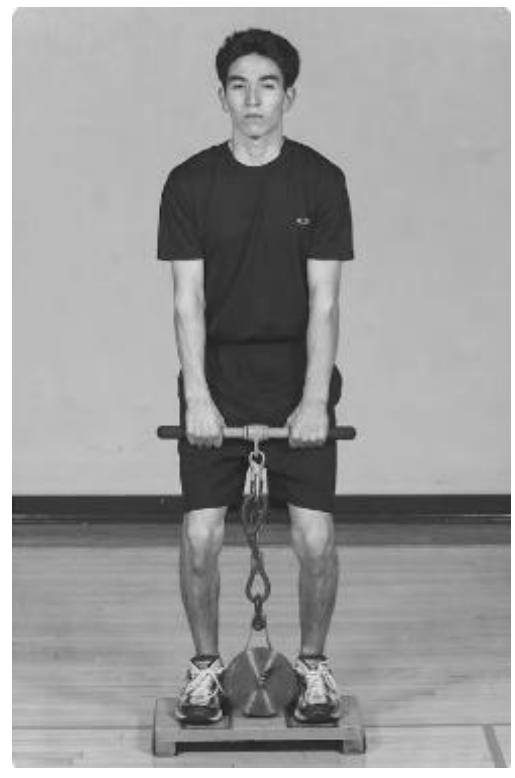

Fig. 1. Leg dynamometer (Heyward et al 2014).

\section{Correlation of lower limb muscle strength, BMI and BBS}

Correlation of lower limb muscle strength of the respondents and $\mathrm{BBS}$ as a basis for determining fall risk can be seen in Table 2. Good and excellent muscle strength has a low risk of falls, and vice versa $(\mathrm{p}=0.000$; correlation coefficient 0.744 ).

Table 3 shows that lower limb muscle strength has a strong correlation with BMI $(\mathrm{p}=0.000$; correlation coefficient 0.607. Respondents who are obese or underweight) have weaker leg muscle strength.

Analysis of BMI with balanced/BBS also showed a strong correlation $(\mathrm{p}=0.000$; correlation coefficient 0.690), as shown in Table 4. Respondents who had BMI of obesity or thin had a poor balance or a low risk of falls. The more abnormal the respondent's BMI was, the higher the risk of falls.

\section{DISCUSSION}

Of the thirty-nine respondents, after considering inclusion and exclusion criteria, the majority of the respondents were females,as many as $28(71.8 \%)$ patients with the highest age of around 70-79 years $(38.46 \%)$. In general, the mobilization of the respondents was still without using aids $(58.97 \%)$ with the lower limb muscle strength in most of the male respondents $(55.6 \%)$ was in good category, while for the most women $(33.3 \%)$ was in average category. Muscle strength of the respondents according to BMI criteria were mostly normal, which was found in $24(61.5 \%)$ patients. The risk of falls as measured using Berg Balance Scale (BBS), was mostly in low category in 17 $(43.6 \%)$ respondents.

Table 1. Characteristics of respondents

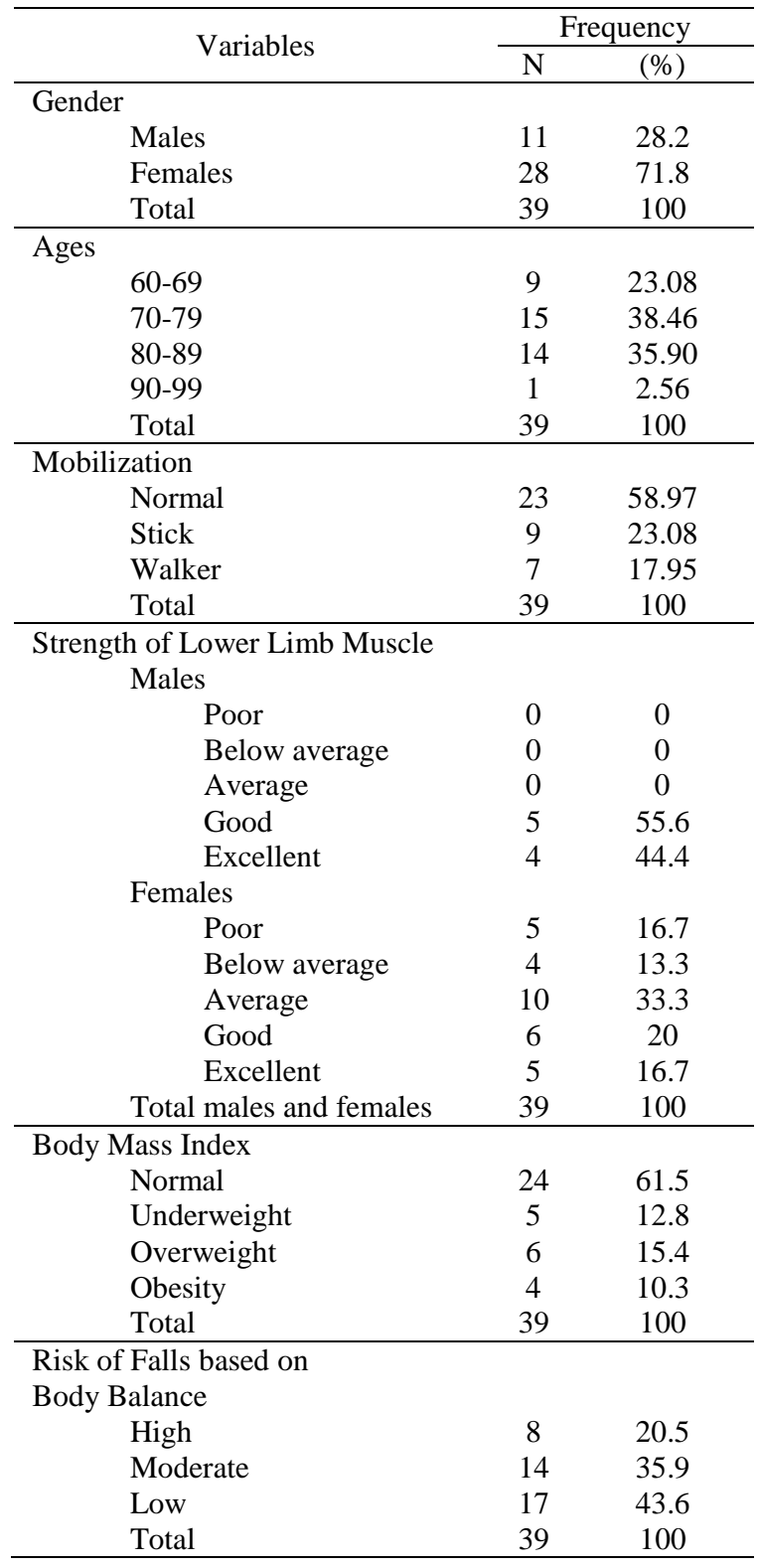

This study at Nursing Home Panti Surya found a strong positive correlation between the strength of the lower limb muscles and the balance of the body in elderly, confirming the reports of previous studies (Reeves \& Dieën 2008, Moreland et al. 2004). There was an agerelated decrease in quadriceps strength, proprioceptive acuity dan postural stability. Ageing compromises 
muscle strength and muscle spindle sensitivity. The ability of older subjects to detect and correct postural sway may be impeded, resulting in decreased stability compared with the younger subjects (Group, Dulwich, \& Grove, 1998).

Table 2. Results of measurement and correlation of lower limb muscle strength with body balance based on risk of falls in elderly at Nursing Home Panti Surya in 2018

\begin{tabular}{|c|c|c|c|c|}
\hline \multirow{2}{*}{$\begin{array}{l}\text { Muscle } \\
\text { strength }\end{array}$} & \multicolumn{3}{|c|}{$\begin{array}{c}\text { Risk of Falls } \\
n(\%)\end{array}$} & \multirow{2}{*}{$\begin{array}{c}\mathrm{P} \\
(0.05)\end{array}$} \\
\hline & High & Moderate & Low & \\
\hline Excellent & $0(0)$ & $2(22.2)$ & $7(77.8)$ & 0.000 \\
\hline Good & $0(0)$ & $3(27.3)$ & $8(72.7)$ & \\
\hline Average & $0(0)$ & $8(80)$ & $2(20)$ & $\begin{array}{c}\text { Correlation } \\
\text { coefficient } \\
0.744\end{array}$ \\
\hline $\begin{array}{l}\text { Below } \\
\text { average }\end{array}$ & $3(75)$ & $1(25)$ & $0(0)$ & \\
\hline Poor & $5(100)$ & $0(0)$ & $0(0)$ & \\
\hline
\end{tabular}

Table 4. Results of measurement and correlation of Body Mass Index with body balance based on risk of falls in the elderly at Nursing Home Panti Surya in 2018

\begin{tabular}{lcccc}
\hline \multicolumn{1}{c}{$\begin{array}{l}\text { Body } \\
\text { Mass }\end{array}$} & \multicolumn{3}{c}{ Risk of Falls } & \multirow{2}{*}{$\mathrm{P}(0.05)$} \\
\cline { 2 - 4 } Index & High & Moderate & Low & \\
\hline Normal & $0(0)$ & $2(8.3)$ & $22(91.7)$ & 0.000 \\
\hline Underweight & $4(80.0)$ & $1(20.0)$ & $0(0)$ & Correlation \\
Overweight & $0(0)$ & $6(100)$ & $0(0)$ & coefficient \\
Obesitas & $4(100)$ & $0(0)$ & $0(0)$ & 0.690 \\
\hline
\end{tabular}

A study on the association between body balance and falls in elderly found several factors that causing body balance disorders, ie the effects of aging, accidents, and certain diseases. However, age or the effect of aging is the main factors that cause balance disorders in elderly due to the decrease in muscle strength (Braz et al 2016). Lazy lifestyle and lack of physical activity can reduce muscle strength or tone. Muscle strength plays an important role in maintaining human balance (Janssen et al 2018).

Correlation study of BMI with body balance in elderly showed a strong positive correlation. If the body mass index increasingly leads to normal values, the body balance measured by the risk of falling is also lower. Likewise, if the BMI goes away from normal values, ie if a person experiences underweight, overweight, and obesity, the balance will tend to be por with the risk of falls ranging from moderate to high The study found that individuals with a larger waist circumference and heavier body mass showed difficulty in performing several body movements, such as bending, kneeling, standing, and even sitting (Janssen et al., 2018).

Body overweight greatly affects walking and balance skills because it affects both in terms of changes in the body's center point and higher levels of fat than muscle mass in the body (Hassinen et al 2005). Greve et al (2007) found a positive correlation between BMI and increased postural instability (greater shifts required in order to keep postural balance). Patients with BMI greater than $30 \mathrm{~kg} / \mathrm{m} 2$ maintain shorter times in balance and longer times unbalanced as compared with nonobese individuals, such that obesity would influence the limits of postural stability (Greve et al 2007).

This study also found a strong correlation between lower limb muscle strength and BMI. Elderly respondents who are underweight tend to have less lower limb muscles, which may also be related to the presence of sarcopenia. Sarcopenia is common in adults over the age of 65 years and increases with age. BMI is a strong predictor of skeletal muscle mass in women and men (Iannuzzi-sucich et al. 2002) This lower leg muscle weakness results in a decrease in balance as measured by the risk of falls. However, this study did not measure muscle mass and observe the presence of sarcopenia, so further research is needed to observe the impact of sarcopenia on the functional conditions of the elderly and its prevention.

Table 3. Results of measurement and correlation of lower limb muscle strength with the Body Mass Index (BMI) in the elderly at Nursing Home Panti Surya in 2018

\begin{tabular}{lccccccc}
\hline \multirow{2}{*}{ IMT } & \multicolumn{5}{c}{ Muscle strength } & \multirow{2}{*}{ P $(0,05)$} \\
\cline { 2 - 6 } & Excellent & Good & Average & Below average & Poor & \\
\hline Normal & 9 & 11 & 4 & 0 & 0 & 0 \\
Underweight & 0 & 0 & 1 & 2 & 2 & \\
Overweight & 0 & 0 & 5 & 1 & 0 & Correlation coefficient \\
Obesitas & 0 & 0 & 0 & 1 & 3 & 0.607 \\
$\quad$ Total & 9 & 11 & 10 & 4 & 5 & \\
\hline
\end{tabular}




\section{CONCLUSION}

The strength of lower limb muscles has a strong positive correlation with body balance in elderly. The higher the muscle strength, the lower the risk of falls in the elderly. BMI has a strong positive correlation with body balance in elderly. The more the BMI far from normal, the higher the risk of falls.

\section{REFERENCES}

Berg K, Wood-Daphinee S, William JI, GD (n.d.) (1989). Physiotherapy Canada 41. doi 10.3138_ptc.41.6.304] Berg, Katherine - Measuring balance in the elderly-preliminary development of an instrument.pdf

Braz J, Petra S, Sá C, Santana RF (2016). Postural balance in the elderly with mild cognitive impairment?: Relationship to Accidental Falls, 67-75

Darmojo B, Martono H (2015). Buku ajar geriatri: Ilmu kesehatan lanjut usia. (H. Martono \& K. Pranarka, Eds.) 5th Ed. Jakarta Badan Penerbit Fakultas Kedokteran Universitas Indonesia

Greve J, Alonso A, Bordini, ACPG, Camanho GL, Greve J, Alonso A, ... Correlation G (2007). Clinical science correlation between body mass index and postural balance $62,717-720$

Group P, Dulwich U, Grove ED (1998). Quadriceps function, proprioceptive acuity and functional performance. Healthy Young, Middle-Aged And Elderly Subjects, 55-62
Hassinen M, Komulainen P, Lakka TA, Väisänen SB, Rauramaa R (2005). Associations of body composition and physical activity with balance and walking ability. The Elderly, 298-306

Heyward HV, Gibson, Ann (2014). Advanced fitness assessment and exercise prescription. 7th Ed. Available from https://doi.org/10.1249/00005768199202000-00023

Iannuzzi-sucich M, Prestwood KM, Kenny AM (2002). Prevalence of sarcopenia and predictors of skeletal muscle mass. Healthy, Older Men and Women 57, 772-777

Indonesia PK (2018). Profil Kesehatan Indonesia 2017.

Janssen I, Katzmarzyk PT, Ross R (2018). Waist circumference and not body mass index explains obesity- related health risk 1-3, 5-7.

Jung H, Yamasaki M (2016). Association of lower extremity range of motion and muscle strength with physical performance of community-dwelling older women. Journal of Physiological Anthropology, 1-7. Available from https://doi.org/10.1186/s40101-0160120-8

Moreland JD, Richardson ÃJA, Goldsmith CH, Clase CM (2004). Muscle weakness and falls in older adults: A Systematic review and meta-analysis, 1121-1129

Prasetya MA, Yoga A (2015). The association between intake of energy, protein and physical activity with nutritional status of elderly people 4, 52-59

Reeves ND, Dieën JHV (2008). Identi W cation of elderly fallers by muscle strength measures, 585-592. Available from https://doi.org/10.1007/s00421-0070613-6 